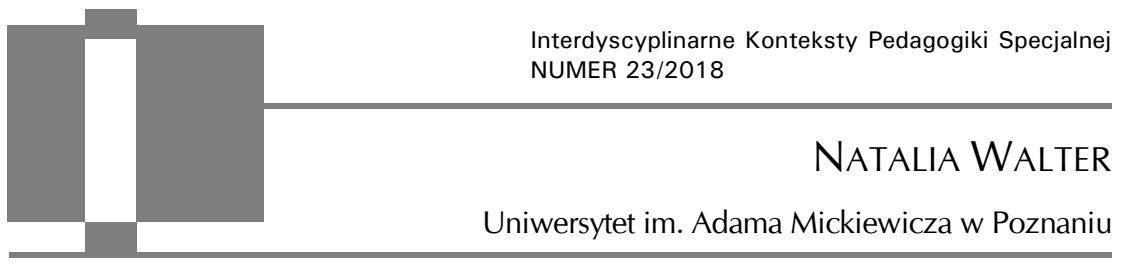

\title{
Internetowe wsparcie społeczne
}

ABSTRACT: Natalia Walter, Internetowe wsparcie spoteczne [Online social support]. Interdyscyplinarne Konteksty Pedagogiki Specjalnej, nr 23, Poznań 2018. Pp. 29-58. Adam Mickiewicz University Press. ISSN 2300-391X. DOI: https://doi.org/10.14746/ ikps.2018.23.02

New media are the tools that support human's intellectual functioning. For many people with disabilities they may become the sole opportunity for accessing information, communicating, learning or working. On the other hand, new media also provide a space for social interactions that could affect the process of coping with critical events, both ordinary and traumatic ones. The key concept for the discussion is internet-based social support, defined as support available online to a person dealing with a critical event which needs to be overcome with external resources coming from virtual groups comprising people experiencing difficulties of a similar nature, in the past or currently. The author posed the question whether internet social support is ubiquitous, and what it manifests itself. To answer this, she conducted quantitative and qualitative research. The data collected then became the basis for analysis and theoretical considerations.

KEY WORDS: social support, internet, supporting role of the media, compensation

\section{Wprowadzenie}

Człowiek w biegu życia doświadcza różnych wydarzeń, które kształtują jego sposób myślenia, wpływają na działanie i postrzeganie rzeczywistości. Niektóre z nich, choć mocno ingerują w utarty schemat funkcjonowania, są przewidywalne, wpisane $\mathrm{w}$ naturalny roz- 
wój. Mają zatem charakter normatywny. Należą do nich narodziny pierwszego dziecka $\mathrm{w}$ rodzinie, zawarcie związku małżeńskiego, rozpoczęcie nowej pracy czy śmierć współmałżonka w końcowym etapie życia. Czasem pojawiają się też wydarzenia krytyczne, których nie da się przewidzieć i których wystąpienie powoduje stres traumatyczny. Są to zwykle kataklizmy, ale też poważne choroby, niepełnosprawność, śmierć kogoś bliskiego. Ze stresem wywołanym przez wydarzenia krytyczne, zarówno rozwojowe, jak i sytuacyjne, ludzie radzą sobie $\mathrm{w}$ różny sposób, m.in. korzystając z określonych zasobów. Według Richarda S. Lazaurusa i Susan Folkman ${ }^{1}$ należą do nich zasoby fizyczne (takie jak zdrowie i energia), psychologiczne (pozytywne przekonania), a także kompetencje $\mathrm{w}$ zakresie rozwiązywania problemów oraz społeczne (w tym wsparcie społeczne).

Nowe media to $\mathrm{z}$ jednej strony narzędzia funkcjonowania w przypadku wielu osób z niepełnosprawnościami mogą stać się jedyną szansą na dostęp do informacji, komunikowanie, uczenie się czy pracę. Z drugiej strony - to przestrzeń, w której zachodzą interakcje społeczne mogące wpływać na radzenie sobie w przypadku wystąpienia wydarzenia krytycznego, zarówno o charakterze normatywnym (rozwojowym), jak i traumatycznym. Kluczowym pojeciem dla moich rozważań uczyniłam internetowe wsparcie społeczne. Definiuję je jako pomoc dostępną online dla jednostki znajdującej się w sytuacji krytycznej, której przezwyciężenie wymaga wykorzystania zewnętrznych zasobów pochodzących z grup wirtualnych, skupiających osoby zmagające się, w przeszłości lub obecnie, z trudnościami o podobnym charakterze. Celem takiego wsparcia jest powrót do dobrostanu psychicznego człowieka. Wyróżniłam pięć zasadniczych rodzajów wsparcia społecznego, które są dostrzegalne także w internecie: emocjonalne (rozszerzone o tzw. współtowarzyszenie, poczucie obecności innych, wspólnotowość), informacyjne, instrumentalne, materialne oraz duchowe ${ }^{2}$.

${ }^{1}$ R.S. Lazarus, S. Folkman, Stress, Appraisal and Coping, Springer, New York 1984.

${ }^{2} \mathrm{H}$. Sęk, R. Cieślak, Wsparcie społeczne - sposoby definiowania, rodzaje i źródła wsparcia, wybrane koncepcje teoretyczne, [w:] Wsparcie spoteczne, stres $i$ zdrowie, red. H. Sęk, R. Cieślak, Wydawnictwo Naukowe PWN, Warszawa 2004, s. 11-28. 
Wsparcie informacyjne (poznawcze) jest jedną z najczęściej spotykanych form społecznego wsparcia internetowego. Informacje udzielane przez internautów mają sprzyjać lepszemu zrozumieniu sytuacji problemowej. Najczęściej są one zamieszczane na indywidualnych stronach WWW, na portalach i wortalach tworzonych przez grupy wsparcia, stowarzyszenia, organizacje oraz osoby prywatne, na forach i grupach dyskusyjnych. Wsparcie informacyjne jest z natury praktyczne i zawiera trzy zasadnicze podkategorie: udzielanie rad, nakierowywanie oraz nauczanie ${ }^{3}$. Niemal wszystkie prośby o udzielenie wsparcia informacyjnego są bezpośrednie, powszechnie kierowane (zazwyczaj nie ma wyraźnego, jednostkowego adresata), gdyż nie wiążą się z przełamywaniem barier społecznych: nie wywołują obawy przed napiętnowaniem, przekraczaniem granic intymności. „W przeciwieństwie do kontaktu twarzą w twarz, ludzie szukający pomocy w Internecie muszą otwarcie wyrazić swoją prośbę" 4 . Rolą wsparcia informacyjnego online jest, po pierwsze, rzetelne przekazywanie sprawdzonych, uniwersalnych informacji (wyników badań na dużej próbie, opracowań eksperckich) i po drugie - udostępnianie jednostkowych doświadczeń, które są nietypowe (zindywidualizowane), silnie uwarunkowane sytuacją (kontekst), stanem psychicznym, fizycznym i emocjonalnym.

Wsparcie instrumentalne, zdaniem Heleny Sęk i Romana Cieślaka ${ }^{5}$, ma za zadanie przekazywać informacje o konkretnych sposobach postępowania, rozwiązywania problemów, dostarczać niezbędnych wskazówek. Jest zatem szczególną, ukonkretnioną formą wsparcia informacyjnego. Według niektórych autorów jest jego integralną częścią, podobnie jak wsparcie o charakterze edukacyjnym $^{6}$. Daje odpowiedź na pytanie - gdzie mam się udać po pomoc w sytuacji, w której niespodziewanie się znalazłem? Co może mnie czekać? Czego mogę się spodziewać?

${ }^{3}$ A. Bambina, Online social support. The Interplay of Social Networks and ComputerMediated Communication, Cambria Press, New York 2007.

4 P. Wallace, Psychologia Internetu, Dom Wydawniczy Rebis, Poznań 2001.

${ }^{5}$ H. Sęk, R. Cieślak, op. cit., s. 11-28.

${ }^{6}$ A. Bambina, op. cit. 
Działalność charytatywna, czyli przejaw najbardziej namacalnego wsparcia materialnego, jest silnie widoczna w internecie. Dotyczy ona zarówno wsparcia grupowego, czyli fundacji i stowarzyszeń zajmujących się organizowaniem pomocy finansowej i rzeczowej dla najbardziej potrzebujących, jak i wsparcia indywidualnego. Wsparcie materialne (rzeczowe lub finansowe), tuż obok emocjonalnego, jest niezwykle istotnym czynnikiem przezwyciężania stresu. Gotowość świadczenia pomocy w zakresie współfinansowania leczenia, pomocy w transporcie, dostawy leków, fizycznej pomocy podczas sprawowania opieki nad potrzebującym stanowią ważny komponent radzenia sobie osób, które znalazły się w trudnej sytuacji i w sposób znaczący wpływa na ich dobrostan psychiczny. $\mathrm{W}$ internecie mamy do czynienia $\mathrm{z}$ kilkoma rodzajami wsparcia materialnego: 1) zbiorowe, systemowe organizowanie zbiórek finansowych i rzeczowych na rzecz konkretnych osób (najczęściej dzieci) lub grup i społeczności, 2) indywidualne apele o wsparcie jednostkowe i odpowiedź na nie, 3) pomoc udzielana ad hoc w prospołecznie powstałych grupach wsparcia online.

Najbardziej dostrzegalną formą wsparcia online jest wsparcie emocjonalne. Jego rolą jest zapewnienie poczucia bezpieczeństwa, towarzyszenie, podtrzymywanie, zapewnianie o miłości i dowartościowywanie, okazywanie sympatii i zrozumienia7. W sytuacji stresowej czy trudnej odgrywa ono ogromną rolę w powrocie do dobrostanu psychicznego. Wielu autorów podkreśla znaczenie tego wsparcia, wyodrębniając dodatkowo kategorię współtowarzyszenia (ang. companionship), czyli zapewniania o trwaniu przy, podkreślania zainteresowania, zachęcania do dzielenia się podstawowymi informacjami, by łatwiej wejść w społeczność online ${ }^{8}$. Wsparcie emocjonalne obecne jest zarówno w grupach wirtualnych (forach, portalach społecznościowych), jak też w blogach i komentarzach internautów. W sytuacjach silnie stresowych ludzie często zaczyna-

7 P.A. Thoits, Stress, coping, and social support processes: Where are we? What next?, “Journal of Health and Social Behavior" 1995, nr Ext. 53, s. 53-79.

8 A. Bambina, op. cit. 
ją pisać blogi po to, by odreagować napięcie. Jest to dla nich forma autoterapii, pomocy udzielonej samemu sobie, ale także szansa na uzyskanie wsparcia emocjonalnego. W komentarzach do blogów pojawiają się wyrazy współczucia, wiele osób pragnie okazać pomoc, dodać otuchy. Wsparcie emocjonalne na forach internetowych przejawia się poprzez wyrazy zrozumienia/empatii, poparcie, afirmację, okazywanie sympatii oraz troskę?.

\section{Przegląd badań}

Badania prowadzone nad zjawiskiem wsparcia społecznego online obejmują rozmaite obszary tego zagadnienia, koncentrując się najczęściej wokół konkretnych chorób. Publikacje oraz opisane w nich wyniki badań dotyczących wsparcia społecznego online osób (lub rodzin) zmagających się z chorobą nowotworową zostały przeanalizowane przez Y. Alicia Hong, Nina C. Peña-Purcell i Marcia G. Ory ${ }^{10}$. Zebrały one szczegółowe wyniki z 762 artykułów dotyczących tematu. Stwierdzili, że w społeczeństwie informacyjnym, w jakim żyjemy, oczywiste staje się poszukiwanie wsparcia społecznego o charakterze emocjonalnym czy informacyjnym. Rośnie też liczba osób zmagających się z chorobami nowotworowymi, którzy sięgają właśnie po wsparcie online. Y.A. Hong, N.C. Peña-Purcell i M.G. Ory ${ }^{11}$ wyodrębnili różne publikacje, kategoryzując je według rodzaju nowotworu, sposobów prowadzenia badań, doboru próby i wielu innych czynników. Najobszerniejszą grupę badań stanowią takie, które koncentrują się na wirtualnych grupach wsparcia kobiet cierpiących na nowotwory piersi. Kolejne obejmują społeczności

${ }^{9}$ N. Walter, Internetowa kultura pomagania, [w:] Kultura mediów, ciało i tożsamość - konteksty socjalizacyjne i cywilizacyjne, red. W. Jakubowski, S. Jaskulska, Oficyna Wydawnicza “Impuls", Kraków 2011, s. 177-188.

10 Y.A. Hong, C.N. Peña-Purcell, M.G. Ory, Outcomes of online support and resources for cancer survivors: A systematic literature review, "Patient Education and Counseling" 2012, Vol. 86(3), s. 288-296.

11 Ibidem. 
zaniedbane, takie jak mniejszości albo osoby o niskim statusie ekonomicznym, głównie posługujące się językiem angielskim (rzadziej badania dotyczą grup z innych niż Wielka Brytania lub Stany Zjednoczone regionów). Większość badaczy odnotowała pozytywne efekty wsparcia społecznego online. Badania jakościowe szczegółowo opisały doświadczenia wirtualne, natomiast ilościowe - przedstawiły różne aspekty dobrostanu psychospołecznego, uwzględniającego jakość życia, poziom stresu, radzenie sobie dzięki wsparciu oraz dostęp do informacji na temat nowotworów. Wskazano na wyniki badań grupy online, której uczestnicy wskazali jej znaczenie w zmniejszeniu negatywnych emocji, podniesienie kompetencji w zakresie funkcjonowania $\mathrm{z}$ chorobą nowotworową. Obecność wsparcia społecznego, głównie - emocjonalnego, ale także informacyjnego w wirtualnej grupie rodziców dzieci z chorobą nowotworową odnotowali: Neil S. Coulson, David H. Gustafson ${ }^{12}$. Podobne wyniki uzyskali D.M. Gustafson, Meg E. Wise, Fiona McTavish $\mathrm{i}$ in. ${ }^{13}$ badający grupę kobiet $\mathrm{z}$ nowotworem piersi, dalej - Paula Klemm, Michelle Hurst, S.L. Dearholt, S.R. Trone14, Morton Lieberman, Stefani Russo'5, Joshua Fogel, Steven Albert, Freya Schnabel, B.A. Ditkoff, A.I. Neugut16, Cornelia F. van Uden-Kraan, Constance H. Drossaert, Erik Taal i in. ${ }^{17}$ oraz wielu innych.

12 N.S. Coulson, N. Greenwood, Families affected by childhood cancer: an analysis of the provision of social support within online support groups, "Child: Care, Health and Development" 2012, Vol. 38(6), s. 870-877.

${ }^{13}$ D.M. Gustafson, M. Wise, F. McTavish, J.O. Taylor, W. Wolberg, J. Steward, Development and pilot evaluation of a computer-based support system for women with breast cancer, "Journal of Psychosocial Oncology" 1994, nr 11, s. 69-93.

14 P. Klemm, M. Hurst, S.L. Dearholt, S.R. Trone, Gender differences on Internet cancer support groups, "Computers Informatics Nursing" 1999, nr 17, s. 65-72.

15 M.A. Lieberman, S. Russo, Self help groups and the Internet: breast cancer newsgroups, "International Journal of Self-Help \& Self-Care” 2002, nr 1, s. 323-344.

16 J. Fogel, S.M. Albert, F. Schnabel, B.A. Ditkoff, A.I. Neugut, Internet use and social support in women with breast cancer, "Journal of Health Psychology" 2002, nr 21, s. 398-404.

17 C.F. van Uden-Kraan, C.H. Drossaert, E. Taal, B.R. Shaw, E.R. Seydel, M.A. van de Laar, Empowering processes and outcomes of participation in online sup-port 
Najobszerniej przedstawione zostały badania Antoniny Bambiny ${ }^{18}$, która analizowała funkcjonowanie grupy społecznej online skupionej wokół forum, które określiła mianem WO-Nowotwór $(\mathrm{WO}=$ Wsparcie Online). Zbadała dogłębnie wszystkie konwersacje między uczestnikami niemoderowanej grupy, które były prowadzone przez dwa wybrane tygodnie. Stwierdziła, że na forum wypowiadają się zarówno mężczyźni, jak i kobiety, w różnym wieku i pochodzący z różnych stron świata. Ich wspólną cechą jest doświadczenie choroby nowotworowej - wypowiadają się osoby chore, członkowie rodzin, czasem też - lekarze, terapeuci oraz opiekunowie. Baza postów i logów pochodzących z 2000 r. została poddana badaniom, którym służyło wyodrębnienie schematu kodów. Wszystkie 1149 wypowiedzi zostały pogrupowane i przyporządkowane do poszczególnych podkategorii. Okazało się, że najczęściej występującą kategorią było współtowarzyszenie (56,7\% wypowiedzi), następnie - wsparcie emocjonalne $(48,2 \%)$ i na końcu - wsparcie informacyjne $(38,6 \%)$. Badania przeprowadzone przez A. Bambinę $e^{19}$ wykazały obecność wsparcia społecznego online, głównie o charakterze emocjonalnym oraz współtowarzyszącym, na forum, gdzie obowiązuje komunikowanie zapośredniczone przez komputer i brak jest kontaktów twarzą w twarz.

Istnieje też szereg badań nad wsparciem społecznym online funkcjonującym $w$ grupach osób cierpiących na choroby, których ujawnienie $\mathrm{w}$ życiu rzeczywistym bywa trudne. Badania prowadzone przez Phoenix K.H. Mo i Neil Stuart Coulson ${ }^{20}$ nad wirtualnymi grupami osób chorych na HIV/AIDS wykazały, iż stanowią one przestrzeń funkcjonowania społecznego, która pozwala na

groups for patients with breast cancer, arthritis, or fibromyalgia, "Qualitative Health Research" 2008, nr 18, s. 405-417.

18 A. Bambina, op. cit.

${ }^{19}$ Ibidem.

${ }^{20}$ P.K.H. Mo, N.S. Coulson, Are online support groups always beneficial? A qualitative exploration of the empowering and disempowering processes of participation within HIV/AIDS-related online support groups, "International Journal of Nursing Studies" 2014, vol. 51(7), s. 983-993. 
wymianę wsparcia informacyjnego oraz emocjonalnego, poprzez dzielenie się doświadczeniem, łączność z innymi osobami (świadomość ich obecności), odnalezienie zrozumienia, pomoc innym. Ponadto stwierdzono, że uczestnictwo w wirtualnych grupach online może wzmacniać optymizm, dobrostan psychiczny (społeczny i emocjonalny), ułatwiać radzenie sobie z chorobą, relacje $z$ lekarzami oraz zwiększać wiedzę dotyczącą HIV.

Istnieje spora liczba badań obejmująca grupy wsparcia społecznego on-line rodziców dzieci zmagających się z chorobami, zespołami genetycznymi i/lub niepełnosprawnością. Takie badania przeprowadziły na przykład Tessen Clifford i Patricia M. Minnes ${ }^{21}$. Dotyczyły one wirtualnej grupy wsparcia dla matek dzieci ze spektrum autyzmu. Badania miały zweryfikować, czy udział w takiej grupie powoduje zmiany w zakresie nastroju, poziomu gniewu, złości, stresu rodzicielskiego oraz pozytywnej percepcji. Badaczki nie odnotowały żadnych istotnych różnic w wymienionych obszarach, ale wskazały, że ankietowani rodzice zdecydowanie wskazywali na pozytywne znaczenie grupy online, którą postrzegali jako pomocną.

Na gruncie polskim badania nad rodzicami, a konkretnie nad takimi, które są zainteresowane opieką zastępczą nad dzieckiem prowadziła Katarzyna Tomsia22. Przeanalizowała ona posty umieszczone na forum dyskusyjnym, które pogrupowała na kategorie: emocjonalne, instrumentalne oraz informacyjne. Stwierdziła znaczącą przewagę komunikatów informacyjnych (28\% postów) nad instrumentalnymi (24\%) i emocjonalnymi (tylko 8\%) ${ }^{23}$. Badania Anety Jarzębińskiej24 dotyczące forum przeznaczonego dla rodzi-

21 T. Clifford, P. Minnes, Logging On: Evaluating an Online Support Group for Parents of Children with Autism Spectrum Disorders, "Journal of Autism and Developmental Disorders" 2013, vol. 43(7), s. 1662-1675.

${ }^{22} \mathrm{~K}$. Tomsia, Internet jako źródto wsparcia dla osób zainteresowanych opiekq zastępcza nad dzieckiem, [w:] Psychologiczne konteksty Internetu, red. B. Szmigielska, Wydawnictwo WAM, Kraków 2009, s. 179-193.

23 Ibidem.

24 A. Jarzębińska, Internetowe forum dyskusyjne jako źródło społecznego wsparcia rodziców (w sytuacji wady letalnej płodu), [w:] Dymensje poradnictwa i wsparcia społecznego 
ców w sytuacji wady letalnej płodu doprowadziły do zidentyfikowania wskaźników wsparcia społecznego, głównie o charakterze emocjonalnym i duchowym. Obserwowalne były też wypowiedzi o charakterze wsparcia informacyjnego oraz wartościującego. Wirtualne wspólnoty kobiet przygotowujących się do wydarzenia rozwojowego, jakim jest macierzyństwo badała Katarzyna Barani25. Wskazała ona na relację między zaangażowaniem w forum a czerpaniem z niego wsparcia informacyjnego. Kobiety aktywnie uczestniczące w dyskusjach, czujące przynależność do wirtualnej grupy częściej i intensywniej poszukiwały wsparcia online niż pochodzącego z innych źródeł. Internet okazał się być najważniejszym, obok lekarza, źródłem wsparcia informacyjnego dla kobiet w ciąży. Dopełnieniem są jakościowe analizy wirtualnych zachowań nastoletnich dziewcząt, które zaszły w ciążę i w przestrzeni wirtualnej poszukują wsparcia, którego nawet tam nie znajdują ${ }^{26}$ oraz badania nas wirtualnym wizerunkiem rodzicielstwa ${ }^{27}$ i wsparcia online w zakresie wychowania ${ }^{28}$.

\section{Metody badań}

Obserwując przez wiele lat rozmaite zachowania internautów, dostrzegłam, oprócz tych silnie uwidocznionych - niepożądanych,

w perspektywie interdyscyplinarnej, red. M. Piorunek, Wydawnictwo Naukowe UAM, Poznań 2015, s. 177-200.

${ }^{25}$ K. Barani, Wirtualne wspólnoty kobiet na forach Internetowych jako źródło wsparcia w przygotowaniu do macierzyństwa, [w:] Całe życie w sieci, red. B. Szmigielska, Wydawnictwo Uniwersytetu Jagiellońskiego, Kraków 2008, s. 177-204.

26 A. Skowrońska-Pućka, (Nie)wirtualne problemy nastoletnich matek. Potrzeba wsparcia, [w:] Rodzina - młodzież - dziecko. Szkice z teorii i praktyki pomocy psychopedagogicznej i socjalnej, red. M. Piorunek, J. Kozielska, A. Skowrońska-Pućka, Wydawnictwo Naukowe UAM, Poznań 2013, s. 231-242.

27 N. Walter, Obraz rodzicielstwa w polskim Internecie, czyli co czytaja i o czym dyskutują współczesne matki, „Biuletyn Edukacji Medialnej” 2012, nr 1, s. 16-26.

${ }^{28}$ N. Walter, Wsparcie wychowawcze online, [w:] Człowiek - Media - Edukacja, red. J. Morbitzer, E. Musiał, KTiME, Kraków 2013, s. 419-427. 
działania produktywne, ugruntowane odpowiedzialnością za drugiego człowieka oraz altruizmem. Zastanowiły mnie i zainteresowały postawy prospołeczne, tak bardzo pożądane i potrzebne we współczesnym świecie. Dlatego zadałam sobie pytanie, czy internet może służyć wsparciu społecznemu rozumianemu jako pomoc dostępną online dla jednostki znajdującej się w sytuacji krytycznej, której przezwyciężenie wymaga wykorzystania zewnętrznych zasobów pochodzących z grup wirtualnych, skupiających osoby zmagające się, w przeszłości lub obecnie, $\mathrm{z}$ trudnościami o podobnym charakterze. Przedmiotem moich analiz empirycznych uczyniłam powszechność i dostępność oraz charakterystykę wsparcia społecznego obecnego $\mathrm{w}$ polskim internecie, $\mathrm{w}$ ujęciu pedagogicznym, w tym - przyczyny, cel, jakość interakcji, efektywność oraz edukacyjny charakter.

Projektując badania, posłużyłam się modelem ex post facto (odmianą eksploracyjną), ponieważ wyodrębnione przeze mnie problemy mają charakter istotnościowy. Obszar badań, jakim jest internet, wyznacza metody, przy pomocy których odpowiadam na nurtujące mnie problemy badawcze: Jaka jest powszechność wsparcia społecznego on-line? oraz: Jak przejawia się wsparcie społeczne $\mathrm{w}$ internecie? (każdemu z nich przyporządkowano problemy szczegółowe). Wsparcie społeczne, w tym także wsparcie społeczne online, wpisuje się w konkretne biografie ludzkie. Dlatego też, oprócz wstępnych badań o charakterze ilościowym (metoda sondażu diagnostycznego oraz metoda netnograficzna analizy dokumentów zastanych, tu: opublikowanych $\mathrm{w}$ internecie rozmówców i wypowiedzi zawartych na forach internetowych, zapisów dzienników online, czyli tzw. blogów oraz tekstów umieszczonych na stronach WWW), przeprowadziłam badania jakościowe.

Wstępne badania sondażowe zostały przeprowadzone wśród studentów pedagogiki (studiów stacjonarnych, niestacjonarnych, podyplomowych oraz trzeciego wieku), czyli osób, którym bliska jest kwestia wsparcia społecznego, udzielania pomocy i działań prospołcznych. W sondażu diagnostycznym wzięło udział 656 osób. W sondażu wzięły udział osoby w wieku od 18 do 60 lat, pochodzą- 
ce ze wszystkich województw polskich. Wszystkie osoby badane miały dostęp do internetu i korzystały $\mathrm{z}$ niego regularnie ( $\mathrm{w}$ większości codziennie).

Do ilościowych badań netnograficznych wybrałam pięć forów internetowych (wirtualnych grup wsparcia). Wszystkie te fora dotyczą wydarzeń krytycznych, które pojawiły się w życiu wypowiadających się internautów. Razem przeanalizowane szczegółowo zostały 5524 posty zawarte w 344 wątkach zbiorczych. Do badań zostało wybrane forum rodziców dzieci przedwcześnie urodzonych, zawierające 132804 posty, a analizowane wątki pochodziły z pierwszej połowy $2015 \mathrm{r}$. Głównymi uczestnikami forum są kobiety - matki, które dzielą się problemami dotyczącymi dzieci, dyskutują o formach opieki szpitalnej, rehabilitacji, rokowaniach, chorobach, lekarzach oraz problemach emocjonalnych. Kolejne forum ma charakter stricte pomocowy, służy wsparciu materialnemu i informacyjnemu (163 247 postów). Z założenia jest moderowane przez matki, choć pojawiają się tu też sporadycznie mężczyźni oferujący np. pomoc prawną. Celem forum jest konkretna pomoc rzeczowa (finansowa, żywnościowa itp.) osobom, które nie mogą poradzić sobie $\mathrm{z}$ utrzymaniem rodziny. Trzecie $\mathrm{z}$ wybranych przez mnie forów poświęcone zostało szeroko rozumianemu zdrowiu. Od początku istnienia powstało 357426 postów (analizowane pochodzą ze stycznia i lutego 2015 r.). Ideą forum jest rozmowa o problemach ze zdrowiem swoim lub osób bliskich. Kolejne, z wybranych do badań, należy do grupy cieszących się ogromną popularnością parentingowych forów „rówieśniczych”, które skupiają rodziców dzieci mających urodzić się $\mathrm{w}$ określonym miesiącu danego roku. Istnieją tu np. „Lipcówki 2007”, „Kwietniowe Mamy 2011” czy „Mamy wrzesień 2006". Wybrane do badań forum dotyczy dzieci urodzonych w 2008 r. (113 558 postów), a analizie poddane zostały wątki z sierpnia i września 2008 r. Ostatnie analizowane ilościowo forum zostało poświęcone osobom rozwodzącym się, które borykają się z trudnościami o charakterze emocjonalnym, szukają porady prawnej lub chcących podzielić się własnym doświadczeniem. Posty (389 689) zamieszczane są przez osoby, które pojawiają się jed- 
norazowo, przypadkowe oraz przez stałych użytkowników, którzy dzielą się swoim doświadczeniem oraz posiadaną wiedzą o charakterze prawnym, skarbowym czy psychologicznym. Ideą jest wspieranie się wzajemne osób, które znalazły się w sytuacji rozwodu.

Badania jakościowe stanowią istotną część moich analiz. Dają odpowiedź na część pytań badawczych, dla których analizy ilościowe były niewystarczające lub dawały niepełny obraz. Zastosowaną przeze mnie metodą badawczą było studium przypadku, dzięki któremu mogłam poddać analizie jednostkowe losy ludzkie uwikłane w określone sytuacje trudne. Moim celem stał się dokładny opis ludzkich działań online w sytuacji wydarzenia krytycznego, przy uwzględnieniu możliwie wielu jego aspektów, także z zakresu oddziaływań edukacyjnych. Decydując się na studium przypadków, wykorzystałam takie techniki badawcze, jak wywiad narracyjny oraz analizę dokumentów zastanych. Studium przypadków, w ramach którego zastosowałam technikę wywiadu eksperckiego oraz narracyjno-biograficznego, objęło osiem osób. Do badań jakościowych netnograficznych dobranych zostało pięć forów internetowych, które wcześniej poddane były analizom ilościowych

\section{Wyniki badań ilościowych}

Prowadzona przeze mnie wieloletnia analiza portali internetowych, a zwłaszcza forów, portali społecznościowych i blogów pozwala na sformułowanie tezy, że wsparcie społeczne $w$ internecie jest zjawiskiem powszechnym. Również przeprowadzony sondaż diagnostyczny dostarcza podobnych wniosków. Na pytanie, „czy w przeciągu ostatnich 12 miesięcy korzystałaś/korzystałeś ze wsparcia społecznego online?", aż 41,3\% ankietowanych odpowiedziało twierdząco. Ponieważ uznałam, że części z badanych pytanie nie dotyczyło bezpośrednio (nie mieli do czynienia z sytuacją trudną w przeciągu minionego roku), zapytałam, czy byliby skłonni skorzystać z takiej formy wsparcia. Tu pozytywnej odpowiedzi udzieliło prawie $50 \%$ badanych. Sondaż nie obejmował badania cech pod- 
miotowych osób ankietowanych, które sprzyjałyby lub utrudniały poszukiwanie wsparcia społecznego. Potrzeba wsparcia jest różnorodna: „niektórzy ludzie czują się lepiej, kiedy potrafią opanować trudności sami, bez pomocy innych, i zwracają się o nią tylko w skrajnej sytuacji. Inni czują się bardziej zależni i wyrażają silniejszą potrzebę wsparcia"29. Część badanych nie potrafi wyobrazić sobie własnej reakcji w przypadku sytuacji krytycznej - świadczy o tym odpowiedź „nie wiem”, której udzieliło ponad 28\% osób.

Polskich stron internetowych ( $\mathrm{w}$ tym forów, portali społecznościowych i blogów) zawierających przejawy wsparcia społecznego jest bardzo dużo. Przykładowo, fora, i blogi dotyczące macierzyństwa $-1,4 \mathrm{mln}$, chorób nowotworowych $-0,5 \mathrm{mln}$, chorób psychicznych - ponad 0,5 mln, niepełnosprawności - 0,6 $\mathrm{mln}$, choroby i/lub straty dziecka - 0,3 mln. Analiza zawartości takich stron również dowodzi powszechności przejawów wsparcia społecznego w Internecie. Szczegółowo zostanie to omówione w kolejnych podrozdziałach.

Osoby badane zostały zapytane, co robią w przypadku wydarzenia krytycznego lub wystąpienia sytuacji trudnej (możliwa była więcej niż jedna odpowiedź). Najwięcej osób odpowiedziało, że rozmawia o tym z najbliższymi (z rodziną) - 75\% lub przyjaciółmi - 58\%. $36 \%$ ankietowanych $\mathrm{w}$ takiej sytuacji przeszukuje Internet, a tylko $15 \%$ konsultuje się ze specjalistami.

Analiza wyników badań w zakresie zależności miedzy odpowiedziami osób badanych a zmiennymi demograficznymi wskazała na istnienie związku między wiekiem ankietowanych a ich deklarowaną skłonnością do korzystania ze wsparcia internetowego. Osoby młodsze (wiek poniżej 23,4 lat) częściej deklarowały skłonność do korzystania ze wsparcia w Internecie niż osoby powyżej 25 lat.

Podobna zależność nie wystąpiła w przypadku deklarowanego korzystania ze wsparcia online w przeciągu ostatnich 12 miesięcy.

${ }^{29}$ N. Knoll, R. Schwarzer, Prawdziwych przyjaciót... Wsparcie społeczne, stres, choroba i śmierć, [w:] Wsparcie społeczne, stres i zdrowie, red. H. Sęk, R. Cieślak, Wydawnictwo Naukowe PWN, Warszawa 2004, s. 29-48. 
Tabela 1. Wiek a deklarowana skłonność do korzystania ze wsparcia społecznego online (jednoczynnikowa ANOVA - test F) ( $n=653$; $d f$ międzygrupowe=2; $d f$ wewnątrzgrupowe=653).

\begin{tabular}{|c|c|c|c|c|c|c|c|}
\hline & $\begin{array}{c}\text { TAK } \\
\mathrm{n}=322\end{array}$ & $\begin{array}{c}\mathrm{NIE} \\
\mathrm{n}=146\end{array}$ & $\begin{array}{c}\text { NIE WIEM } \\
\mathrm{n}=188\end{array}$ & \multirow{2}{*}{$\begin{array}{c}\text { Analiza efektów } \\
\text { międzygrupowych }\end{array}$} & \multicolumn{2}{|c|}{$\begin{array}{l}\text { Statystyki } \\
\text { testu F }\end{array}$} & \multirow{2}{*}{$\eta 2$} \\
\hline & $M(S D)$ & $M(S D)$ & $M(S D)$ & & $F$ & $p$ & \\
\hline Wiek & $\begin{array}{c}23,38 \\
(3,725)\end{array}$ & $\begin{array}{l}25,27 \\
(7,685)\end{array}$ & $\begin{array}{c}23,39 \\
(3,965)\end{array}$ & $1>2$ & 8,242 & 000, & 0025, \\
\hline
\end{tabular}

Źródło: opracowanie własne

Wśród czynników sprzyjających poszukiwaniu wsparcia społecznego online badani wskazali na dystans społeczny i anonimowość (69\%), możliwość znalezienia internautów zmagających się $\mathrm{z}$ podobnym problemem (62\%), dostępność wsparcia $\mathrm{w}$ internecie (31\%) oraz, w najmniejszym stopniu, obiektywizm rad udzielanych przez internautów w stosunku do tych pochodzących od osób bliskich (13\%). A zatem niepokój, a nierzadko i wstyd towarzyszący nieradzeniu sobie $\mathrm{z}$ danym wydarzeniem krytycznym jest najczęstszym motywatorem sięgania po anonimowe wsparcie, charakterystyczne dla internetu. Poszukiwanie rzeczywistej pomocy bywa krępujące, zwłaszcza dla osób uchodzących za niezłomne, radzące sobie w każdej, nawet najtrudniejszej sytuacji. Anonimowi internauci nie wypytują, nie wkraczają za bardzo w prywatność, koncentrują się tylko na tym, co zostało wykreowane, na fragmencie przedstawionej tożsamości. Nie są emocjonalnie zaangażowani $\mathrm{w}$ problem, a zatem mogą wspierać $\mathrm{z}$ dystansem, bez roztkliwiania się i rozczulania. Znajdą się zapewne tacy, którzy mieli do czynienia z podobnym problemem, nawet jeśli jest on niezwykle rzadki. Współdzielenie się doświadczeniem z osobami, które przeżyły to samo pomaga $\mathrm{w}$ radzeniu sobie $\mathrm{z}$ sytuacją oraz $\mathrm{w}$ ponownym osiągnięciu dobrostanu psychicznego.

Silnie rozbudowana sieć wsparcia społecznego online dostępna jest dzięki różnym szeroko dostępnym usługom internetowym. 
Badani, którzy zadeklarowali, że w przeciągu ostatnich 12 miesięcy poszukiwali wsparcia społecznego online, zostali poproszeni o wskazanie oraz uporządkowane usług takich, jak blogi osób opisujących podobne doświadczenia, fora dyskusyjne, wortale informacyjne poświęcone danemu zagadnieniu oraz portale społecznościowe oraz grupy dyskusyjne, w zależności od częstotliwości korzystania. Ankietowani, najczęściej wsparcia społecznego online szukają na wortalach tematycznych (często robi to 14,6\% ogólnej liczby wszystkich badanych, a bardzo często - 12,8\%) oraz na forach dyskusyjnych (często - 9,9\% i bardzo często - 12,3\%). Najrzadziej sięgają po blogi (13,3\% nie robi tego nigdy, a 11,8\% bardzo rzadko), portale społecznościowe (nigdy - 11,3\%, bardzo rzadko - 11,6\%) oraz grupy dyskusyjne (nigdy - 11,4\%, bardzo rzadko - 10,7\%).

Analiza wybranych forów, blogów oraz profili portali społecznościowych pod kątem użytych zwrotów i słów kluczowych wyrażających prośbę o wsparcie również wskazała na największą popularność w tym zakresie forów internetowych. Próśb o pomoc oraz wsparcie (zarówno informacyjne, emocjonalne, duchowe, jak i materialne) było odpowiednio: 90961 na wybranych pięciu forach, 134 na czterech blogach oraz 14 na czterech profilach portalu społecznościowego. Wszystkie analizowane strony miały charakter pomocowy lub dotyczyły wydarzeń krytycznych (choroba, zdrowie, niepełnosprawność, macierzyństwo, rozwód). Fora internetowe są największą przestrzenią wymiany doświadczeń, stąd też liczba próśb tam zawartych nie dziwi. W przypadku blogów oraz profili portalu społecznościowego mamy do czynienia z jednostkowymi, indywidualnymi losami życiowymi, stąd wypowiedzi autorów oraz reakcje komentujących internautów są odpowiednio rzadsze i ściśle ukierunkowane. Kolejną sprawą jest anonimowość lub jej brak. W przypadku forów internetowych autorzy i komentatorzy wątków kryją się pod nickami (pseudonimami). Proszenie o pomoc staje się tu więc łatwiejsze, pozbawione warstwy wstydu i zażenowania. Również udzielanie wsparcia jest $w$ takiej sytuacji prostsze. Pisała o tym m.in. Patricia Wallace: „Wiemy, że w środowiskach, które zapewniają większą anonimowość, ludzie są bardziej otwarci 
- a to pomaga zwłaszcza w prowadzonej w sieci terapii oraz sprzyja działalności grup wsparcia"30. W przypadku blogów, a szczególnie - portali społecznościowych autorzy najczęściej podają swoje prawdziwe dane, ponieważ chcą w ten sposób uzyskać konkretne wsparcie, np. finansowe. To zobowiązuje ich do pewnej wstrzemięźliwości, przemyślenia kreowanego wizerunku, który może w przyszłości sprzyjać pozytywny reakcjom osób pragnących udzielić wsparcia.

Osoby, które zostały poddane badaniu sondażowemu najchętniej szukają wsparcia społecznego na portalach tematycznych, czyli wortalach. W zależności od podejmowanej tematyki można wyróżnić strony prowadzone przez: 1) fundacje i stowarzyszenia, 2) prywatne osoby, 3) instytucje i firmy prywatne.

Prowadząc badania, zastanawiałam się, czy wsparcie społeczne online wynika z ograniczonego wsparcia rzeczywistego. Założyłam, że częściej ze wsparcia online korzystać będą te osoby, które mają utrudniony dostęp do specjalistów lub ich bliskie relacje interpersonalne są niewystarczające $w$ przypadku wystąpienia sytuacji trudnych. Dla większości badanych rodzina, przyjaciele oraz/lub współpracownicy są źródłem wsparcia. Dla 52\% ankietowanych zawsze, a dla 42,1\% - często. 4,1\% badanych uważa, że na bliskich w tym zakresie można liczyć sporadycznie, a 0,2\% - w ogóle. 11 osób $(1,7 \%)$ nie oczekuje i nie poszukuje wsparcia u bliskich.

Łatwy dostęp do specjalistów, takich jak lekarz czy psycholog zadeklarowało większość badanych $(68,1 \%)$, natomiast utrudniony - 22,7\%. 60 osób udzieliło innej odpowiedzi (9,1\%). Wśród odpowiedzi dodatkowych najczęściej wskazywano na trudność z odpowiedzią na pytanie - część badanych nie miała do czynienia z wydarzeniem krytycznym w życiu, któremu nie mogliby sprostać samodzielnie lub z niewielkim wsparciem bliskich. Pojawiały się też wypowiedzi dotyczące zbyt długiego czasu oczekiwania na specjalistę lub wysokiej ceny usług prywatnych, trudnego dostępu, braku zaufania, braku profesjonalizmu i niepoważnego potraktowania problemu. Wyniki moich badań nie dały odpowiedzi na pytanie,

30 P. Wallace, op. cit., s. 311. 
dotyczące zbieżności (lub jej braku) między korzystaniem ze wsparcia społecznego online a korzystaniem z usług specjalistów. Nie można jednoznacznie wskazać na istnienie związku w tym zakresie, ani na jego brak.

Istotną kwestią $\mathrm{w}$ przypadku poszukiwania i korzystania ze wsparcia społecznego online jest świadomość zagrożeń towarzyszących tej formie pomocy. Należy tutaj uwzględnić następujące niebezpieczeństwa: 1) internauci chętniej dzielą się swoimi negatywnymi doświadczeniami niż pozytywnymi, stąd ich porady mogą być nieobiektywne, 2) porady/informacje zawarte $w$ internecie pochodzą z niewiarygodnych źródeł - mogą być nierzetelne, 3) dzielenie się doświadczeniem bywa niepełne - brak opisanych szczegółów może skutkować niewłaściwą interpretacją oraz 4) wypowiedzi internautów bywają sformułowane w sposób potęgujący stres. Badani w kwestionariuszu ankiety wybierali więcej niż jedną odpowiedź z listy zagrożeń wymienionych powyżej. Najczęściej wskazywano na odpowiedź 2), czyli niewiarygodność źródeł (78\%), następnie 3) niepełny opis doświadczenia $(53,7 \%), 1)$ nacechowanie negatywne $\mathrm{w}$ wypowiedziach internautów $(40,5 \%)$ oraz 4$)$, czyli spotęgowanie stresu (36,7\%). 25 osób (3,8\%) wskazało na inną odpowiedź. Zauważono, że "poszukiwanie wsparcia online może powodować zamknięcie się na rzeczywisty kontakt z ludźmi, co prowadzi do pogłębienia problemów", konfabulacje (wypowiedzi osób, które nie doświadczyły danego problemu), celowe wprowadzanie w błąd, złośliwy i prześmiewczy charakter niektórych wypowiedzi, powierzchowność, hejterstwo, niewłaściwa interpretacja, nadmierna emocjonalność wypowiedzi, ukryta działalność firm. Kilka osób zauważyło, że ograniczenie się do poszukiwania wsparcia $\mathrm{w}$ internecie może prowadzić do negatywnych skutków, takich jak poczucie osamotnienia, zaburzenia społeczne.

Uczestników sondażu diagnostycznego, którzy zadeklarowali korzystanie ze wsparcia społecznego online $\mathrm{w}$ przeciągu ostatnich 12 miesięcy, zapytałam o rodzaj poszukiwanego przez nich wsparcia. Najczęściej ankietowani de klarowali poszukiwanie wsparcia 
informacyjnego (233 osoby), następnie - instrumentalnego (188 osób), emocjonalnego (29 osób), duchowego (22 osoby) oraz rzeczowego (17 osób). Jeśli chodzi o zawartość konkretnych stron i grup internetowych, badania prowadzone przez innych autorów pokazują, że rozkład wsparcia może być odmienny w zależności od specyfiki danego źródła. I tak np. według Antoniny Bambiny ${ }^{31}$ badającej forum osób cierpiących na nowotwory, wsparcie emocjonalne stanowiło 34,6\% analizowanych wypowiedzi, wsparcie informacyjne 24,8\%, natomiast współtowarzyszenie (poczucie wspólnoty, obecności) - 40,6\%. Badania Katarzyny Barani ${ }^{32}$ nad grupami wsparcia społecznego w kontekście macierzyństwa wskazują z kolei na przewage wsparcia informacyjnego nad emocjonalnym. Dlatego też, oprócz sondażu diagnostycznego, równocześnie dokonałam analizy internetowych grup wsparcia społecznego.

Po dwóch latach obserwacji do badań dobrałam pięć forów internetowych, które poddałam szczegółowej analizie ilościowej. Wybrane posty były dokładnie przeze mnie czytane, a następnie poddawane etykietowaniu. Wypowiedziom przyporządkowywałam kategorie wsparcia w ujęciu funkcjonalnym. Przyjęłam, podobnie jak A. Bambina33 i wielu innych badaczy, że post wspierający może mieć charakter informacyjny, emocjonalny oraz dający poczucie współtowarzyszenia, obecności (ang. companionship), instrumentalny, materialny lub duchowy. Razem przeanalizowane zostały 5524 posty zawarte w 344 wątkach zbiorczych. W zależności od rodzaju forum, jego odbiorców, tematyki oraz specyfiki wzajemnych zależności, zmieniał się rozkład odnajdywanego wsparcia społecznego. Przeanalizowane fora różnią się zakresem i rodzajem udzielanego wsparcia społecznego. Najczęściej oferowana jest pomoc informacyjna, rzadziej - emocjonalna, choć istnieją fora, gdzie jest dokładnie odwrotnie. Poniższy diagram zawiera zestawienie różnych form wsparcia na opisanych wcześniej forach.

\footnotetext{
31 A. Bambina, op. cit.

32 K. Barani, op. cit., s. 177-204.

33 A. Bambina, op. cit.
} 


\section{Wnioski z badań. Dyskusja}

Trudno jednoznacznie stwierdzić, czy wsparcie społeczne w internecie jest powszechne. Jak wynika z badań ilościowych, niespełna 50\% ankietowanych zadeklarowało, że skorzystałoby ze wsparcia internetowego w sytuacji krytycznej, czyli takiej, którą postrzegaliby jako przekraczającą możliwości samodzielnego poradzenia sobie z nią. Jeżeli uwzględnimy wiek badanych, którymi przede wszystkim byli studenci w wieku do 26 lat, może się okazać, że trudność sprawia im myślenie o życiu w kategoriach wydarzeń krytycznych, które mogliby spotkać. Wiek wczesnej dorosłości charakteryzuje się pełnymi optymizmu marzeniami dotyczącymi przyszłości i rzadko w nich pojawia się myśl o ewentualnych trudnościach. Również rodzicielstwo, które jest najbliższym normatywnym wydarzeniem krytycznym w życiu młodych dorosłych, jawi się jako cudowne i pełne szczęścia. Nie są więc w stanie przewidzieć, czy w sytuacji stresu rodzicielskiego sięgnęliby po wsparcie dostępne w Internecie oraz czy byliby gotowi na udział w wirtualnych grupach wsparcia. Brak zainteresowania wsparciem online może też wynikać z innych kwestii, które opisane są w literaturze naukowej, takich jak indywidualne sposoby radzenia sobie ze stresem, cechy osobowości, które wykluczają korzystanie z zewnętrznych zasobów, silnie wspierające najbliższe otoczenie, stanowiące rodzaj kokonu, który gwarantuje bezpieczeństwo ${ }^{34}$. Badania jakościowe, w tym wywiady narracyjnobiograficzne, które nie zostały zaprezentowane w artykule, pokazują, że zainteresowanie wsparciem online wzrasta. Jest to szczególnie widoczne w blogosferze, ale też na forach i w portalach społecznościowych. A zatem, choć jednoznacznie nie mogę stwierdzić, że wsparcie społeczne dostępne w internecie jest powszechne, uważam, że jest ono dostępne oraz wszechstronnie obecne i budzi ogromne zainteresowanie.

Psychologowie kliniczni stwierdzają istnienie indywidualnych różnic w zakresie potrzeby tradycyjnego wsparcia, jego postrzega-

${ }^{34}$ H. Sęk, R. Cieślak, op. cit., s. 11-28. 
nia i przyjmowania ${ }^{35}$. W przypadku wsparcia internetowego jest podobnie. Oprócz zmiennej, jaką jest wydarzenie krytyczne, można wskazać na różnice ze względu na płeć oraz wiek. Badania ilościowe, które przeprowadziłam, nie dają jednoznacznej odpowiedzi, czy kobiety, jak wskazują na to doświadczenia psychologów klinicznych, częściej oferują i poszukują wsparcia niż mężczyźni.

Badania ilościowe wskazują, że nieznacznie częściej ze wsparcia społecznego online korzystają osoby młodsze, poniżej 23. roku życia, dla których internet jest naturalną przestrzenią funkcjonowania społecznego. Osoby poniżej 23. roku życia zazwyczaj nie tworzą jeszcze trwałych relacji partnerskich, natomiast rozluźnieniu ulegają ich pierwotne więzi rodzinne, ze względu na typowy dla tego okresu rozwój społeczny. Pozostawanie w trwałych związkach partnerskich samo w sobie stanowi wsparcie i ułatwia radzenie sobie w sytuacjach stresowych. W przypadku młodych dorosłych, którzy zazwyczaj nie posiadają jeszcze mocnego oparcia, np. ze strony współmałżonka, częściej pojawia się potrzeba korzystania z pomocy z zewnątrz, $\mathrm{w}$ tym pochodzącej z internetu. Jednak, z uwagi na ich wiek i wiążący się z nim częsty brak doświadczenia wydarzenia krytycznego, nie są oni głównymi odbiorcami oraz ofiarodawcami wsparcia społecznego.

Osoby udzielające i korzystające ze wsparcia społecznego online, jak wskazują na to badania jakościowe, to zazwyczaj osoby nastawione prospołecznie, otwarte, aktywne, krytycznie myślące. Cechą, która wyróżnia osoby udzielające wsparcia społecznego online jest altruizm, charakteryzujący internautów o osobowości produktywnej. Odczuwają oni potrzebę troski o innych i w sposób naturalny podchodzą do konieczności bezinteresownej pomocy. Altruizm jest, jak pokazują badania Laura Price, E. Kum-Foong Leong oraz Maria Ryan ${ }^{36}$, czyn-

35 N. Knoll, R. Schwarzer, Prawdziwych przyjaciót... Wsparcie społeczne, stres, choroba i śmierć, [w:] Wsparcie spoteczne, stres $i$ zdrowie, red. H. Sęk, R. Cieślak, Wydawnictwo Naukowe PWN, Warszawa 2004, s. 29-48.

36 L. Price, E. Leong, M. Ryan, Motivations for social Internet use, ANZMAC Conference: Consumer Behaviour, Edith Cowan University 2005, http://www.anzmac. org/conference_archive/2005/cd-site/pdfs/3-Consumer-Beh/3-Price.pdf [dostęp: 7.03.2016]. 
nikiem motywującym do społecznego używania Internetu. P. Wallace $^{37}$ zauważa, że „społeczność sieciowa jest gotowa sobie pomagać zarówno w małych, jak i całkiem dużych sprawach. Najczęściej pomoc ta obejmuje udzielenie informacji, a chęć niesienia pomocy jest jednym z głównych powodów, dla którego ludzie zaglądają do grup dyskusyjnych".

O wsparciu, co warto podkreślić, mówimy wtedy, gdy osoby go sobie udzielające znajdują się w sytuacji stresowej, która jednak nie była poprzedzona ani nie spowodowała $\mathrm{u}$ nich zaburzeń psychicznych.

Podstawową przyczyną poszukiwania wsparcia społecznego online jest znalezienie się w sytuacji wydarzenia krytycznego, którego pojawienie się wywołuje silny stres. Jak pokazały zarówno badania ilościowe, jak i jakościowe, osoby, które poszukują wsparcia w internecie, mogą liczyć przede wszystkim na swe najbliższe otoczenie. Dla większości badanych rodzina, przyjaciele oraz współpracownicy byli źródłem wsparcia. Ankietowani deklarowali też zazwyczaj łatwy dostęp do specjalistów, takich jak lekarz czy psycholog. Z wywiadów narracyjno-biograficznych również wynika, że obecność partnera była niezwykle istotna w sytuacji wydarzenia krytycznego i to właśnie ona stanowiła największe wsparcie. Natomiast dla poradzenia sobie ze stresem koniecznym było zetknięcie się z osobami, które doświadczyły podobnych trudności. Właśnie poznawanie internetowych historii innych pomagało ukierunkować działania i często dawało nadzieję. Poszukiwanie wsparcia w internecie pojawiało się zarówno $\mathrm{w}$ normatywnych, jak i bardzo nietypowych, niezwykle rzadkich sytuacjach.

Jak wynika z badań ilościowych, wśród czynników sprzyjających poszukiwaniu wsparcia społecznego można wyróżnić dystans społeczny i anonimowość (będące najczęściej wskazywaną przyczyną), możliwość znalezienia internautów zmagających się z podobnym problemem, dostępność wsparcia w internecie oraz, $\mathrm{w}$ najmniejszym stopniu, obiektywizm rad udzielanych przez internautów w stosunku do tych pochodzących od osób bliskich.

37 P. Wallace, op. cit., s. 249. 
Kolejną, w wielu sytuacjach, zasadniczą przyczyną korzystania ze wsparcia społecznego online jest możliwość dzielenia się swoim doświadczeniem z osobami, które znalazły się w podobnej sytuacji. Ponadto komunikowanie przez internet i mówienie za jego pośrednictwem o sprawach trudnych jest łatwiejsze i szerzej dostępne. Opowiedzenie trudnej historii w sieci pozwala na dotarcie do wielu odbiorców, ale także pozwala na uporządkowanie myśli, zachowywanie wspomnień. Powodem, dla którego wiele osób dzieli się swoją trudną historią w internecie, jest potrzeba uzyskania wsparcia materialnego - finansowego lub rzeczowego. Prośby takie pojawiają się zarówno na blogach, jak i forach czy portalach społecznościowych.

Przejawy wsparcia społecznego online dostrzec można dzięki różnym usługom internetowym. Badania ilościowe wskazują, że w sytuacji stresowej ankietowani najczęściej korzystają z wortali tematycznych oraz forów, natomiast rzadziej - z blogów, portali społecznościowych oraz grup dyskusyjnych. Taki rozkład pokazuje, że w sytuacji wydarzenia krytycznego najważniejsze są, po pierwsze, profesjonalne informacje oraz po drugie, możliwość prowadzenia dyskusji z osobami zmagającymi się z podobnymi trudnościami.

W ujęciu funkcjonalnym wsparcie społeczne online może mieć charakter informacyjny, emocjonalny, instrumentalny, materialny oraz duchowy. Najczęściej, jak wynika z sondażowych badań ilościowych, w sytuacji stresowej poszukiwane jest wsparcie informacyjne, dalej - instrumentalne. Najrzadziej ankietowani wskazywali na potrzebę odnalezienia $\mathrm{w}$ internecie wsparcia emocjonalnego, duchowego oraz rzeczowego. $Z$ analiz netnograficznych nad forami wynika, że wsparcie, które jest udzielane za pośrednictwem sieci, zależy od rodzaju i tematyki danej grupy wirtualnej. Ujawnienie się na forach internetowych określonej formy wsparcia uzależnione jest od takich cech grupy wirtualnej, jak cel jej powstania, tematyka, zasięg i struktura, skład czy dynamika. Celem funkcjonowania forum może być towarzyszenie w sytuacji wydarzenia krytycznego, wymiana informacji, wymiana doświadczeń, doradztwo oraz zorganizowana pomoc namacalna. Kolejną cechą warunkującą wystąpienie określonych form wsparcia jest tematyka. Fora mogą doty- 
czyć wydarzeń krytycznych o charakterze normatywnym oraz traumatycznym, których doświadczenie pociąga za sobą określone potrzeby wsparcia. Ogromne znaczenie mają też takie aspekty, jak otwartość forum, dostępność, płeć i wiek osób wypowiadających się, tworzenie sieci społecznych lub ich brak, nawiązywanie przyjaźni, konflikty, pełna anonimowość lub ujawnianie fragmentów prywatności. Na wielu forach, wraz z rozwojem i zmianami w zakresie udziału poszczególnych użytkowników, otwarciem na tzw. gości (użytkowników niezarejestrowanych), a także stopniowym radzeniem sobie przez poszczególne osoby z sytuacją stresową, dominują odmienne formy wsparcia.

Badania jakościowe, a w szczególności wywiady narracyjno-biograficzne, pokazują, że poszukiwanie różnych form wsparcia społecznego w Internecie zależy od takich czynników, jak sytuacja stresowa, istnienie stałej i pewnej bezpośredniej sieci społecznej (np. rodziny, przyjaciół), pomoc profesjonalna lub jej brak, a także cechy podmiotowe osoby, która znalazła się w tej sytuacji.

Warto tu także zwrócić uwagę na wsparcie materialne, rzeczowe, które dość często stanowi przyczynę dzielenia się swoją historią online. Zjawiskiem, które staje się powszechne jest finansowanie społecznościowe (ang. crowdfunding), które, w odróżnieniu od tradycyjnych form zbierania funduszy, gdzie dominuje model kilku znaczących donatorów, stanowi sposób zbierania drobnych datków od wielkiej rzeszy drobnych darczyńców.

Z poszukiwaniem wsparcia społecznego online może wiązać się szereg zagrożeń. Jak wynika z moich badań niebezpieczeństwo tkwi w: 1) niewiarygodności porad i informacji pochodzących od internautów, 2) prezentowaniu tylko wąskich fragmentów doświadczeń, zazwyczaj w formie wyłącznie tekstowej (brak opisanych szczegółów może skutkować niewłaściwą interpretacją), 3) skłonności dzielenia się raczej negatywnymi doświadczeniami niż pozytywnymi 4) potęgujących stres wypowiedziach internautów, 5) angażowaniu uwagi i zabieraniu czasu (także nieustannym powracaniu do sytuacji trudnych), 6) uzależnieniach od internetu, 7) osłabieniu naturalnych sieci wsparcia, 8) wypowiedziach obelżywych, wul- 
garnych, prześmiewczych, fałszujących rzeczywistość oraz takich, które są próbą oszustwa różnego typu.

Znalezienie się w sytuacji wydarzenia krytycznego staje się niejednokrotnie przyczynkiem do intensywnego uczenia się. Człowiek, zgodnie z deweyowską koncepcją learning by doing38 czy późniejszymi modelami Davida Kolba ${ }^{39}$ oraz Petera Jarvisa ${ }^{40}$, uczy się poprzez indywidualne doświadczenia. To one stanowią istotny element całożyciowej edukacji, ponieważ warunkują transformację struktur poznawczych, wiedzy i działania. To właśnie one stają się podstawą tak zwanego „uczenia się biograficznego” (ang. biographical learning), czyli takiego, które jest wpisane zarówno w indywidualne losy, jak i w społeczne struktury i kulturowe konteksty interpretacyjne. Uczenie się biograficzne obejmuje tradycyjnie pojmowaną edukację formalną, nieformalną oraz pozaformalną, choć w kontekście indywidualnej historii nie są one wyraźnie zarysowane i łatwe do wyodrębnienia ${ }^{41}$.

W biegu ludzkiego życia, zarówno podczas formalnej, jak i pozaformalnej edukacji, dochodzi do mimowolnego uczenia się, dzięki wykorzystaniu posiadanych zasobów wiedzy, uprzednich doświadczeń i umiejętności działania. Rozwiązując problem, z którym się mamy zmierzyć, angażujemy wszelkie dostępne zasoby wewnętrzne, ale też sięgamy po źródła zewnętrzne, wynikające z funkcjonowania w określonym środowisku i kulturze. Zatem pojawiające się w biografii wydarzenia krytyczne, zarówno normatywne, jak i traumatyczne mobilizują nas do działania oraz do uczenia się. Trafny przykład podała tu jedna z moich respondentek, przywołując aktywność matek dzieci z zespołem Downa, które znajdują wsparcie online od innych mam, będących specjalistkami

38 J. Dewey, How We Think, Heath, New York 1933.

39 D. A. Kolb, R. Fry, Toward an applied theory of experiential learning, [w:] Theories of Group Process, C. Cooper, John Wiley, London 1975.

${ }^{40}$ P. Jarvis, Adult Learning in the Social Context, Croom Helm, London-New York-Sydney 1987.

41 P. Alheit, Podejście biograficzne do całożyciowego uczenia się, "Teraźniejszość człowiek - edukacja" 2011, nr 3(55), s. 7-20. 
od swych własnych dzieci. Żaden profesjonalny terapeuta nie włoży takiego wysiłku intelektualnego i emocjonalnego $\mathrm{w}$ pomoc dziecku, jak jego rodzice. Z badań jakościowych jednoznacznie wynika, że pewne sytuacje krytyczne sprawiają, że człowiek, który musi się z nimi mierzyć, zaczyna błyskawicznie się uczyć. Sięga zarówno do posiadanych, wewnętrznych zasobów wiedzy, odwołuje się do wcześniejszych doświadczeń, aż wreszcie zaczyna wołać o pomoc, szukać wsparcia, także online. Radzenie sobie z wydarzeniem krytycznym polega m.in. na uczeniu się - zdobywaniu informacji na temat sytuacji lub problemu, analizowaniu dostępnych źródeł, strukturyzowaniu posiadanej wiedzy, konsultowaniu z innymi, odwoływaniu się do własnych i cudzych doświadczeń. Elementem biograficznych procesów uczenia się jest zatem również formowanie więzi i procesów społecznych ${ }^{42}$. Jak pokazały moje badania, osoby, które poradziły sobie z wydarzeniem krytycznym, zdobyły dzięki temu wiedzę i umiejętności, którymi dzielą się później z innymi. Stają się zatem uczestnikami procesu uczenia się innych. Na szeroką skalę takie współdziałanie możliwe jest wyłącznie dzięki internetowi. Szczególną rolę edukacyjną przyjmuje wsparcie społeczne online w sytuacji wydarzeń krytycznych, uporanie się z którymi wykracza poza posiadane zasoby własne oraz najbliższego otoczenia. Liczne przykłady znalazły się w wywiadach narracyjno-biograficznych, gdzie silnie uwidacznia się zarówno rola wsparcia emocjonalnego, ale nade wszystko informacyjnego o charakterze edukacyjnym.

Wsparcie społeczne online ujawnia się w sytuacji wydarzenia krytycznego. Podobnie, jak pokazują to inne badania, na przykład Heleny Sęk i Romana Cieślaka ${ }^{43}$, potrzeba wsparcia społecznego online zależy od rodzaju sytuacji stresowej, cech podmiotowych oraz strategii radzenia sobie $\mathrm{w}$ sytuacjach trudnych oraz istniejącej sieci społecznej w najbliższym otoczeniu. Badania ilościowe nie wskazały na istnienie wyraźnej zależności między dostępem do

42 Ibidem.

${ }^{43}$ H. Sęk, R. Cieślak, op. cit., s. 11-28. 
wsparcia bezpośredniego (wśród osób najbliższych oraz specjalistów) a potrzebą korzystania ze wsparcia online. Również osoby, z którymi przeprowadziłam wywiady narracyjno-biograficzne korzystały ze wsparcia online mimo wspierającej obecności najbliższych. Natomiast jest to aspekt, którego nie można jednoznacznie wykluczyć. Ogromne znaczenie ma charakter sytuacji stresowej, charakter wydarzenia krytycznego, z którym ma do czynienia dana osoba oraz jej cechy osobowościowe oraz potrzeby, na przykład korzystania z zewnętrznych zasobów, weryfikowania hipotez z innymi osobami, które mają za sobą podobne doświadczenia, dzielenia się swoją historią.

Wsparcie społeczne online może pełnić rozmaite funkcje. Oprócz bazowej, jaką jest przyczynienie się do radzenia sobie i powrotu do dobrostanu psychicznego, wyróżnić można też funkcję edukacyjną, socjalizacyjną, autokreacyjną i kulturotwórczą. Udzielanie wsparcia społecznego online, oprócz wspomnianego już aspektu edukacyjnego, stanowi istotny element wymiany społecznej oraz tworzenia zasobów kulturowych. Dzielenie się własnym doświadczeniem, przemyśleniami, refleksjami, odkryciami i posiadaną wiedzą stanowi wkład do rozwoju internetowych zasobów, dostępnych szerokiej rzeszy odbiorców. Przedstawienie własnej biografii ma charakter autokreacyjny, wizerunkowy, co z kolei pociąga za sobą zmianę postrzegania siebie, wynikającego z interakcji społecznych, zarówno pozytywnych, jak i negatywnych. Anonimowość, która jest wpisana w istotę internetu ułatwia mówienie o sobie, zwłaszcza na forach dyskusyjnych. Z kolei blogowanie, choć często wiąże się z ujawnieniem fragmentu prywatności, pozwala na przedstawienie szerszego kontekstu i uwypuklenie indywidualnych doświadczeń i refleksji.

Wśród zasadniczych cech wsparcia społecznego online można wskazać jego dostępność, pośredniość, anonimowość (choć nie zawsze jest ona obecna), tekstowość, różnorodność w zakresie form. Niewątpliwym atutem wsparcia udzielanego za pośrednictwem technologii informacyjno-komunikacyjnych jest jego dostępność, wręcz - wszechobecność. Osoby, dla których korzystanie z interne- 
tu jest wpisane $\mathrm{w}$ codzienne funkcjonowanie, w naturalny sposób sięgają do społecznych zasobów online. Dzieje się tak zarówno w sytuacji wydarzeń krytycznych o charakterze normatywnym, jak i traumatycznym. Obarczone jest natomiast konsekwencjami braku bezpośredniości. Często $\mathrm{w}$ sytuacji stresowej człowiek potrzebuje wsparcia fizycznego, namacalnego - przysłowiowego "podania szklanki wody", które z oczywistych względów jest niedostępne online. Jednakże dzięki funkcji komunikacyjnej, którą realizuje Internet, znalezienie osoby, która udzieliłaby właśnie takiego bezpośredniego wsparcia, staje się już możliwe. Anonimowość oraz pokazywanie wybranego fragmentu biografii jest cechą, która sprzyja zachowaniom altruistycznym z jednej strony oraz większej otwartości z drugiej. Charakterystyczną cechą wsparcia społecznego online jest jego tekstowy charakter, który może zarówno ułatwiać, jak i utrudniać przekazywanie informacji oraz mówienie o emocjach. Wczesne badania nad komunikacją zapośredniczoną przez komputer wskazywały na jej ograniczony charakter, uproszczenie, sztywność, brak intymności i otwartości. Później jednakże stwierdzono, że konieczność wypowiadania się $\mathrm{w}$, pozbawionej aspektów pozawerbalnych formie tekstowej przyczyniła się do bardziej przemyślanego i przyjaznego wyrażania myśli, co z kolei dalej stanowi o autorze i jest formą autoprezentacji. Pisanie (a nie mówienie) o sytuacji stresowej sprzyja lepszemu poradzeniu sobie z problemem oraz uporządkowaniu myśli i zaplanowaniu konstruktywnych działań. Komunikowanie oparte na tekście może mieć ogromne znaczenie dla osób, których wygląd odbiega od ogólnie przyjętych standardów i tym samym utrudnia wchodzenie w relacje bezpośrednie. Rozmówcy online pozbawieni są również takich cech fizycznych, jak płeć, wiek, rasa czy niepełnosprawność, co sprzyja nawiązywaniu relacji oraz angażowania się w pomoc lub tej pomocy poszukiwanie ${ }^{44}$.

${ }^{44}$ M. Tanis, Online social support groups, [w:] The Oxford Handbook of Internet Psychology, red. A. Joinson, K. McKenna, T. Postmes, U. Reips, Oxford University Press Inc., New York 2007, s. 139-153; M. White, S.M. Dorman, Receiving social support 
Wsparcie społeczne online ujawnia się, jak pokazują to zarówno badania innych autorów, jak i moje, w różnych formach i rodzajach. Obserwowalne jest wsparcie informacyjne, emocjonalne, instrumentalne (choć wyłącznie w formie porad, nie jako pomoc namacalna), materialne oraz duchowe. Szczególnie w niektórych forach internetowych oraz stronach portali społecznościowych, pełniących funkcję wirtualnych grup wsparcia obecne jest współtowarzyszenie, czyli takie wypowiedzi, które kształtują wspólnotowy charakter dyskusji.

\section{Bibliografia}

Alheit P., Podejście biograficzne do całożyciowego uczenia się, „Teraźniejszość człowiek - edukacja" 2011, nr 3(55), s. 7-20.

Bambina A., Online social support. The Interplay of Social Networks and Computer-Mediated Communication, Cambria Press, New York 2007.

Barani K., Wirtualne wspólnoty kobiet na forach Internetowych jako źródto wsparcia w przygotowaniu do macierzyństwa, [w:] Całe życie w sieci, red. B. Szmigielska, Wydawnictwo Uniwersytetu Jagiellońskiego, Kraków 2008, s. 177-204.

Clifford T., Minnes P., Logging On: Evaluating an Online Support Group for Parents of Children with Autism Spectrum Disorders, "Journal of Autism and Developmental Disorders" 2013, Vol. 43(7), s. 1662-1675.

Coulson N.S., Greenwood N., Families affected by childhood cancer: an analysis of the provision of social support within online support groups, "Child: Care, Health and Development" 2012, Vol. 38(6), p. 870-877.

Davison K.P., Pennebaker J.W., Dickerson S.S., Who talks? The social psychology of illness support groups, "American Psychologist" 2000, nr 55, s. 205-217.

Dewey J., How We Think, Heath, New York 1933.

Fogel J., Albert S.M., Schnabel F., Ditkoff B.A., Neugut A.I., Internet use and social support in women with breast cancer, "Journal of Health Psychology" 2002, nr 21, s. 398-404.

Gustafson D.M., Wise M., McTavish F., Taylor J.O., Wolberg W., Steward J., Development and pilot evaluation of a computer-based support system for women with breast cancer, "Journal of Psychosocial Oncology" 1994, nr 11, s. 69-93.

online: implications for health education, "Health Education Research", 2001, nr 16 (6), s. 693-707; K.P. Davison, J.W. Pennebaker, S.S. Dickerson, Who talks? The social psychology of illness support groups, "American Psychologist" 2000, nr 55, s. 205-217. 
Hong Y.A., Peña-Purcell C.N., Ory M.G., Outcomes of online support and re-sources for cancer survivors: A systematic literature review, "Patient Education and Counseling" 2012, Vol. 86(3), s. 288-296.

Jarvis P., Adult Learning in the Social Context, Croom Helm, London-New YorkSydney 1987.

Jarzębińska A., Internetowe forum dyskusyjne jako źródło społecznego wsparcia rodziców (w sytuacji wady letalnej płodu), [w:] Dymensje poradnictwa $i$ wsparcia społecznego w perspektywie interdyscyplinarnej, red. M. Piorunek, Wydawnictwo Naukowe Uniwersytetu im. Adama Mickiewicza w Poznaniu, Poznań 2015, s. 177-200.

Klemm P., Hurst M., Dearholt S.L., Trone S.R., Gender differences on Internet cancer support groups, “Computers Informatics Nursing” 1999, nr 17, s. 65-72.

Knoll N., Schwarzer R., Prawdziwych przyjaciót... Wsparcie społeczne, stres, choroba i śmierć, [w:] Wsparcie społeczne, stres $i$ zdrowie, red. H. Sęk, R. Cieślak, Wydawnictwo Naukowe PWN, Warszawa 2004, s. 29-48.

Kolb D.A., Fry R., Toward an applied theory of experiential learning, [in:] Theories of Group Process, ed. C. Cooper, John Wiley, London 1975.

Lazarus R.S., Folkman S., Stress, Appraisal and Coping, Springer, New York 1984.

Lieberman M.A., Russo S., Self help groups and the Internet: breast cancer newsgroups, "International Journal of Self-Help \& Self-Care" 2002, nr 1, s. 323-344.

Mo P.K.H., Coulson N.S., Are online support groups always beneficial? A qualitative exploration of the empowering and disempowering processes of participation within HIV/AIDS-related online support groups, "International Journal of Nursing Studies" 2014, vol. 51(7), s. 983-993.

Price L., Leong E., Ryan M., Motivations for social Internet use, ANZMAC Conference: Consumer Behaviour. Edith Cowan University, 2005, http://www.anzmac.org/ conference_archive/2005/cd-site/pdfs/3-Consumer-Beh/3-Price.pdf [dostęp: 7.03.2016].

Sęk H., Cieślak R., Wsparcie społeczne - sposoby definiowania, rodzaje i źródta wsparcia, wybrane koncepcje teoretyczne, [w:] Wsparcie społeczne, stres i zdrowie, red. H. Sęk, R. Cieślak, Wydawnictwo Naukowe PWN, Warszawa 2004, s. 11-28.

Skowrońska-Pućka A., (Nie)wirtualne problemy nastoletnich matek. Potrzeba wsparcia, [w:] Rodzina - młodzież - dziecko. Szkice z teorii i praktyki pomocy psychopedagogicznej i socjalnej, red. M. Piorunek, J. Kozielska, A. Skowrońska-Pućka, Wydawnictwo Naukowe Uniwersytetu im. Adama Mickiewicza w Poznaniu, Poznań 2013, s. 231-242.

Tanis M., Online social support groups, [w:] The Oxford Handbook of Internet Psychology, red. A. Joinson, K. McKenna, T. Postmes, U. Reips, Oxford University Press Inc., New York 2007, s. 139-153.

Thoits P.A., Stress, coping, and social support processes: Where are we? What next?, "Journal of Health and Social Behavior" 1995, no. Ext. 53, s. 53-79. 
Tomsia K., Internet jako źródto wsparcia dla osób zainteresowanych opieka zastępczą nad dzieckiem, [w:] Psychologiczne konteksty Internetu, red. B. Szmigielska, Wydawnictwo WAM, Kraków 2009, s. 179-193.

van Uden-Kraan C.F., Drossaert C.H., Taal E., Shaw B.R., Seydel E.R., van de Laar M.A., Empowering processes and outcomes of participation in online sup-port groups for patients with breast cancer, arthritis, or fibromyalgia, "Qualitative Health Research" 2008, nr 18, s. 405-417.

Wallace P., Psychologia Internetu, Dom Wydawniczy Rebis, Poznań 2001.

Walter N., Internetowa kultura pomagania, [w:] Kultura mediów, ciało i tożsamość konteksty socjalizacyjne i cywilizacyjne, red. W. Jakubowski, S. Jaskulska, Oficyna Wydawnicza „Impuls”, Kraków 2011, s. 177-188.

Walter N., Internetowe wsparcie społeczne, Wydawnictwo Naukowe Uniwersytetu im. Adama Mickiewicza w Poznaniu, Poznań 2016.

Walter N., Obraz rodzicielstwa w polskim Internecie, czyli co czytaja i o czym dyskutuja współczesne matki, „Biuletyn Edukacji Medialnej” 2012, nr 1, s. 16-26.

Walter N., Wsparcie wychowawcze online, [w:] Człowiek - Media - Edukacja, red. J. Morbitzer, E. Musiał, KTiME, Kraków 2013, s. 419-427.

White M., Dorman S.M., Receiving social support online: implications for health education, "Health Education Research" 2011, nr 16(6), s. 693-707. 